\title{
Interest and Resilience in Online Mathematics Learning and Its Impact on Concept Understanding
}

\author{
Farman $^{\mathrm{a},{ }^{*}}$, Fitriyani Hali ${ }^{\mathrm{a}}$, Muhammad Rawal ${ }^{\mathrm{c}}$ \\ ${ }^{\mathrm{a}}$ Universitas Sembilanbelas November Kolaka, Kolaka, Indonesia \\ ${ }^{b}$ SMA Negeri 8 Kendari, Kendari, Indonesia
}

\begin{abstract}
This study aimed to determine students' interest in learning and mathematical resilience in online learning and their impact on understanding concepts. The research used in this study is Ex-post facto, namely research with a quantitative approach that aims to test or explain the relationship between variables through hypothesis testing. The research was conducted at SMA Negeri 8 Kendari class XI students in the 2020/2021 academic year. The research sample was 24 students of Class XI IPA 1 SMA Negeri 8 Kendari. Sampling using purposive sampling technique based on students' readiness to participate in online learning without network constraints. The instruments used in this study were questionnaires and tests. Questionnaires were used to obtain information about mathematical interest and resilience. In contrast, the test is used to obtain data about the ability to understand concepts. The data analysis technique used in this study was descriptive analysis technique and inferential analysis, which was carried out with the help of the SPSS 22 computer program. The results showed that students' interest in online learning had a significant influence on concept understanding. Likewise, students' mathematical resilience in online learning has a significant influence on conceptual understanding. The analysis results also show a significant effect of interest and resilience together on understanding mathematical concepts. The percentage contribution of the influence of interest and resilience variables on understanding mathematical concepts is $77.8 \%$, while other variables influence the rest.
\end{abstract}

Keywords: interest, resilience, online, mathematic, understanding

\section{Introduction}

Mathematics is one of the branches of science that contributes to the progress of science and technology (Yadav, 2020). Mathematics is an instrument for the development of other sciences (Peter, 2011). Mathematics is a unique subject and is a fundamental part of the school curriculum (Gafoor \& Kurukkan, 2015). Given the importance of mathematics in transforming human civilization, mathematics needs to be mastered by students from the elementary level (Kusmaryono, 2018). Mathematics needs to be learned by students because mathematics is a means of thinking to foster the development of critical thinking patterns (Firdaus et al., 2015), creativity (Sari et al., 2019) and supports overall personal development (Hodaňová \& Nocar, 2016). Thus, mathematics lessons have a very important position in the progress of a nation in order to be able to compete with other nations in an increasingly competitive global life.

In learning mathematics, the most important thing that students must have is the ability to understand concepts. Students must understand the concepts that exist in mathematics. Understanding this concept needs to be instilled in students from an early age, namely since the child is still in elementary school (Romadon \& Mahmudi, 2019). Students must organize and communicate their mathematical thinking, construct knowledge by interpreting their understanding, and connect with prior knowledge and real-world experience (Benson-O'Connor et al., 2019). Understanding concepts is needed to master teaching materials that contain many formulas so that students can understand the concepts in the

\footnotetext{
* Corresponding author.

E-mail address: farman.math@yahoo.co.id (Farman)
} 
material and are skilled at using various procedures in a flexible, accurate, efficient, and precise manner (Dini et al., 2018). In addition, the ability to understand concepts has an important role for students in solving mathematical problems with other concepts so that a broader understanding of concepts is obtained (Purwasih, 2015).

Student's ability to understand mathematical concepts is still relatively low. It is in line with research conducted by Mawaddah \& Jannah (2017), which states that students' mathematical understanding abilities are still relatively low. There are several indicators of mathematical understanding that have not been met. Aripin (2015) that students still have difficulty at the level of mathematical understanding ability, so it can be concluded that students' mathematical understanding abilities are still low. Low comprehension ability has implications for the low achievement of students. It is evident from the results of the 2018 Program for International Student Assessment (PISA) study, which shows that the mathematical ability of Indonesian students is ranked 35 out of 41 countries in the world (OECD, 2018). The same results in the 2015 Trends In Mathematics and Science Study (TIMSS) showed that Indonesian students' achievement in Mathematics was ranked 44th out of 49 countries (Mullis et al., 2015). This fact shows that the quality of Indonesian mathematics education is still low on a national and international scale.

The quality of mathematics education in Indonesia is increasingly visible with the Corona Virus Disease 2019 (covid19). Covid-19 has become a global pandemic requiring education to make adjustments by changing face-to-face learning methods to online. Online learning is an effective solution in learning at home to break the chain of the spread of COVID-19 (Mujib \& Yunita, 2021). However, the problem faced by education in Indonesia during online learning during this pandemic is student participation in learning. Student participation in online interactive learning only reached 38.8\% (Muhammad, 2020). According to the Ministry of Education and Culture survey, even the results state that the obstacles to online learning are that many cannot carry out digital-based learning. The learning process from home is more dominant in doing task questions. Amelia et al. (2020) stated that the teacher only provides material files and ends with giving assignments that cause students to become confused in understanding the material. Students' convenience of learning with an online system is also many complaints; they find it easier to understand the lecturer's material offline than online learning (Dewantoro \& Rachmawati, 2020).

The low participation of students in online interactive learning is due to the inappropriate use of media and online learning designs. It is in line with SMA Negeri 8 Kendari, where WhatsApp groups dominate learning activities. It becomes less giving a touch of innovation and attracts students' interest in participating in learning activities. Students only get materials and assignments through messages or files provided by the teacher. This activity does not support resilience and enthusiasm for online learning. This of course has an impact on students' common mathematical understanding of their lessons, especially mathematics.

Student participation in online learning is influenced by student interests (Suhartini, 2018; Gustiani, 2020) and resilience (Shi, 2020; Amelia et al., 2020; Beale, 2020). The existence of students' interest and resilience towards learning can encourage students to be active and enthusiastic in learning, especially in learning mathematics. Interest in learning has the main characteristic of carrying out self-selected and fun learning activities to form habits in a person (Vainikainen et al., 2015). Resilience is defined as a universal capacity that can prevent the influence of one's condition when facing certain problems or pressures (Dewantoro \& Rachmawati, 2020) and overcome all difficulties and obstacles during mathematics learning (Amelia et al., 2020). Good mathematical resilience is needed to prepare mathematics students to face obstacles and succeed in learning mathematics (Muthuprasad et al., 2021). Students with strong mathematical resilience will have an adaptive attitude in adjusting to the environment, can face the uncertainty of problems and challenges, solve problems logically and flexibly, seek creative solutions to challenges, are curious, learn from experience, can control themselves, be aware of his feelings and have a strong social network (Hendriana, 2012).

Several studies show a relationship between interest, resilience, and understanding of concepts in learning mathematics. Research Lin et al. (2016) stated a relationship between interest in learning and understanding students' concepts. Likewise, students' mathematical resilience in learning significantly influences understanding concepts (Amelia et al., 2020; Nurjannah \& Marlina, 2021). In learning mathematics, interest can be seen as fun and interest in understanding mathematics further, and the habit of studying mathematics (Trisniawati et al., 2019). Mathematics is an abstract subject that causes students to be less interested in learning, especially students with common conceptual understanding and low achievement (Yeh et al., 2019). Interest does not arise spontaneously because of participation, experience, and 
habits when studying or working (Azmidar et al., 2017). In contrast, resilience is a student's attitude that affects learning mathematics in solving various mathematical problems, which is carried out through adaptation even though students are in challenging situations (Nurjannah \& Marlina, 2021). Resilience attitudes can help students adjust to difficulties and achieve high academic achievement and success because they believe that successful learning results from effort and perseverance (Permatasari et al., 2021).

Based on this description, it is necessary to review students' mathematical interest and resilience in learning, especially online learning during the Covid-19 era. In addition, so far, several studies have only tried to overcome the problem of low understanding of concepts from the outer side of students through the use of models, approaches, methods, and learning tools but have not revealed students' internal factors in more depth. So it is necessary to explore mathematical interest and resilience and their impact on students' understanding of concepts in online learning.

\section{Research Method}

\subsection{Types of research}

The type of research used in this study is Ex-post facto, a research with a quantitative approach that aims to test or explain the relationship between variables through hypothesis testing. This research is a representation of the basic characteristics of quantitative research that aims to test the theory.

This study was intended to determine the effect of interest and mathematical resilience on understanding mathematical concepts of class XI students of SMA Negeri 8 Kendari.

\subsection{Sample}

The research sample was 24 students of Class XI IPA 1 SMA Negeri 8 Kendari. Sampling using purposive sampling technique based on students' readiness to participate in online learning without network constraints.

\subsection{Research design}

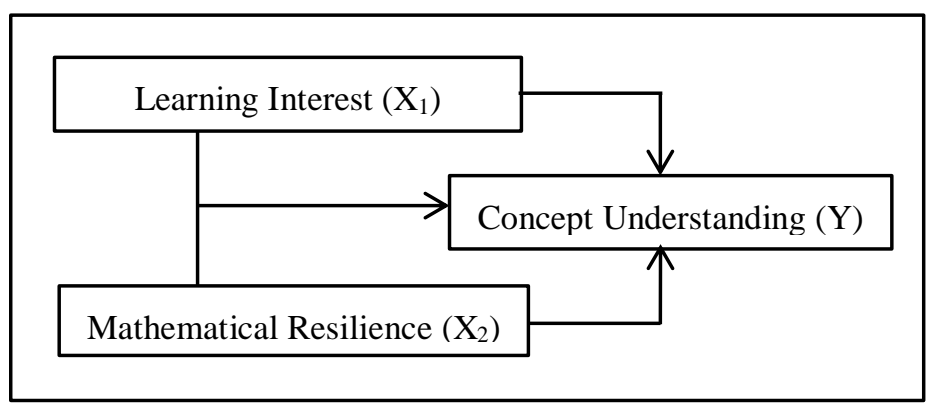

Fig. 1. Research design.

\subsection{Instruments and Data Collection Techniques}

The instrument used in this research is to use a questionnaire and a test. Questionnaires were used to obtain information about mathematical interest and resilience. In comparison, the test was used to obtain data about the ability to understand the concept. The data collection technique of this research was carried out through tests, questionnaires, and documentation.

\subsection{Data analysis technique}

The data analysis technique used in this research is descriptive analysis technique and inferential analysis. Quantitative data were analyzed descriptively to see a sample picture of interest, mathematical resilience, and understanding of concepts. The inferential analysis aims to test the hypothesis of interest and mathematical resilience on students' understanding of concepts. Data analysis was carried out with the help of the SPSS 22 computer program. 


\section{Results and Discussion}

\subsection{Result}

The results of the descriptive analysis of the variables of interest in learning, resilience, and understanding of students' mathematical concepts are shown in the following table

Table 1. Results of descriptive statistical analysis.

\begin{tabular}{lccccc}
\hline Variable & $\mathrm{N}$ & Minimum & Maximum & Mean & Std. Deviation \\
\hline Interest & 24 & 56 & 90.70 & 72.88 & 8.49 \\
Resilience & 24 & 54.70 & 94.70 & 70.93 & 9.89 \\
Understanding & 24 & 30 & 100 & 73.96 & 24.41 \\
\hline
\end{tabular}

Table 1 for the learning discipline variable shows that the highest score is 88.33 , the lowest score is 59.17 , the mean is 76.63, and the standard deviation is 8.27. The achievement motivation variable shows that the highest score is 91.11 , the lowest score is 40.00 , the mean is 71.43 , and the standard deviation is 13.07 . The learning achievement variable shows that the highest score is 85.00 , the lowest score is 50.00 , the mean is 69.79 , and the standard deviation is 8.90 .

Furthermore, an inferential analysis was conducted, which first tested the analytical prerequisites for hypothesis testing, namely normality, linearity, multicollinearity, and heteroscedasticity. The results of the normality test are presented in the table 2.

Table 2. Normality test results.

\begin{tabular}{lccc}
\hline & $\mathrm{N}$ & $\alpha$ & Sig. \\
\hline $\begin{array}{l}\text { Unstandardized } \\
\text { Residual }\end{array}$ & 24 & 0,05 & 0,200 \\
\hline
\end{tabular}

Based on the table 2, it is obtained that the significance value $=0.2>0.05$, which means the data is normally distributed.

Table 3. Results of linearity test analysis

\begin{tabular}{lccc}
\hline & & $\alpha$ & Sig. \\
\hline Understanding and Interest & $\begin{array}{c}\text { Deviation } \\
\text { from linearity }\end{array}$ & 0,05 & 0,178 \\
Understanding and Resilience & & 0,05 & 0,336 \\
\hline
\end{tabular}

Value of Sig. Deviation from linearity between Understanding and Interest $=0.178>0.05$ means that Understanding and Interest are linear. While the value of Sig. Deviation from linearity between Understanding and Resilience $=0.336$ $>0.05$, which means there is linearity between understanding and resilience.

Table 4. The results of the collinearity test analysis

\begin{tabular}{lccc}
\hline & \multicolumn{3}{c}{ Collinearity Statistics } \\
\hline Model & Sig. & Tolerance & VIF \\
\hline (Constant) & 0,00 & & \\
\hline Interest & 0,025 & 0,682 & 1,465 \\
\hline Resilience & 0,000 & 0,682 & 1,465 \\
\hline
\end{tabular}

Based on the table 4, the value of VIF $=1.476>10$ and the tolerance value $=0.678>0.1$, which means that there is no multicollinearity. Furthermore, the heteroscedasticity test was carried out, namely, seeing the similarity of the variance of the residuals from one observation to another observation. The results of the heteroscedasticity test are shown in the following scatterplot. 


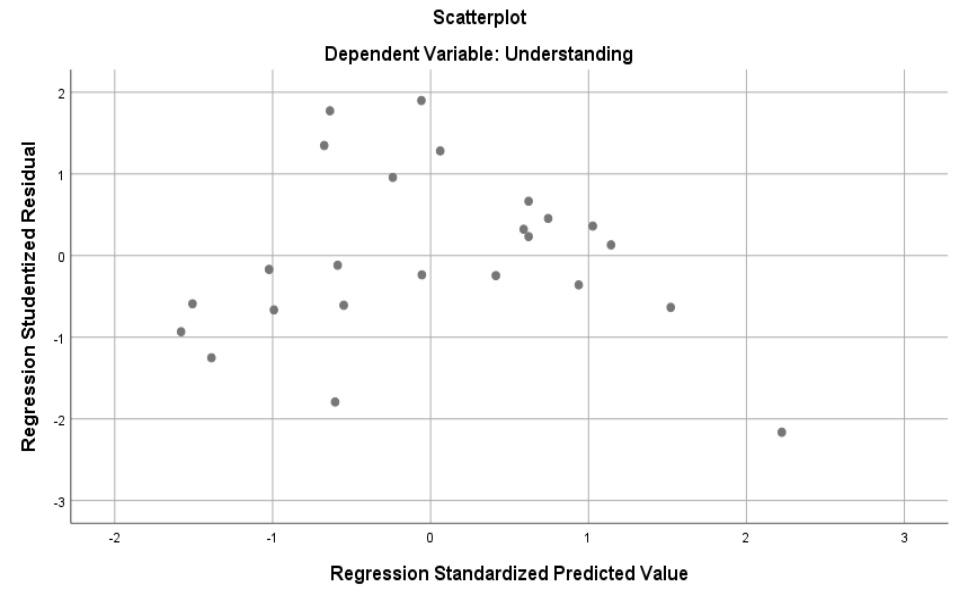

Fig. 2. Heteroscedasticity test scatterplot.

Based on the figure 2, it shows that there is no certain pattern on the graph, such as gathering in the middle, narrowing then widening, or widening and then narrowing. It means that there is no heteroscedasticity.

Table 5. Results of regression analysis.

\begin{tabular}{lccccc}
\hline \multicolumn{7}{c}{ Unstandardized Coefficients } \\
\hline Model & $\mathrm{B}$ & Std. Error & $\alpha$ & $\mathrm{t}$ & Sig. \\
\hline (Constant) & $-107,518$ & 22,788 & 0,05 & $-4,718$ & 0,000 \\
Interest & 0,864 & 0,357 & 0,05 & 2,417 & 0,025 \\
Resilience & 1,671 & 0,307 & 0,05 & 5,441 & 0,000 \\
\hline
\end{tabular}

Based on the data presented in table 5 , we get constant $=-107.518$, interest variable $(X 1)=0.864$ and Resilience variable $(\mathrm{X} 2)=1.671$. So the regression equation model is $\mathrm{Y}=-107.518+0.864 \mathrm{X} 1+1.671 \mathrm{X} 2$. Table 5 also shows that the interest model has sig. $=0.025<0.05$ which means interest has an influence on understanding the concept. While the resilience model has sig. $=0.000<0.05$ which means resilience has an influence on understanding the concept.

Table 6. Simultaneous regression analysis results

\begin{tabular}{lccc}
\hline Model & F & $\alpha$ & Sig. \\
\hline Regression & 36,832 & 0,05 & 0,000 \\
\hline
\end{tabular}

Sig value. $=0.000>0.05$, which means that interest and resilience have a significant influence on understanding mathematical concepts.

Table 7. Results of the coefficient of determination

\begin{tabular}{lcccc}
\hline Model & $\mathrm{R}$ & $\mathrm{R}$ Square & $\begin{array}{c}\text { Adjusted } \\
\text { R Square }\end{array}$ & $\begin{array}{c}\text { Std. Error of } \\
\text { the Estimate }\end{array}$ \\
\hline 1 & 0,882 & 0778 & 0,757 & 12,0296 \\
\hline
\end{tabular}

Based on table 7, it can be seen that the coefficient of determination $\mathrm{R} 2=0.778$. This shows that the percentage of the contribution of interest and resilience variables together on understanding mathematical concepts is $77.8 \%$, while the rest is influenced by variables that are not included in this research model. 


\subsection{Discussion.}

Online learning offers students to study anywhere without being limited by time and distance restrictions. Although the phenomenon of student participation in learning is lacking, the study results also show that there are still many students interested in online learning because of the flexibility it offers. The development of online learning aims to create a wider learning space for students, and the design must meet the needs of students. Interest in online learning refers to how students like to use online tools and online platforms for learning (Shi, 2020). Interest is shown by the feeling of pleasure, interest, attention, curiosity, and activeness of students in understanding the material provided by the teacher. Lin et al. (2016) stated a relationship between interest in learning and understanding of students' concepts. This is in line with our research, which concluded that students' interest in online learning significantly influences conceptual understanding.

The results showed that students' mathematical resilience in online learning had a significant influence on concept understanding. This is in line with what Amelia et al. (2020) that to understand the material given by the teacher, students need mathematical resilience. Nurjannah \& Marlina (2021) stated that students' resilience attitudes could affect the ability to understand mathematical concepts in solving various mathematical problems that are carried out through adaptation. If a student has high mathematical resilience, then learning mathematics is a challenge to solve mathematical problems in various ways. Meanwhile, students with moderate or low mathematical resilience assume that learning mathematics is a difficulty they face, so that it becomes a problem in solving mathematical problems. Therefore, when teachers choose and apply a mathematics learning approach to help students overcome difficulties in achieving mathematical abilities and develop an attitude of mathematical resilience (Wibowo et al., 2018).

The results showed that simultaneously there was a significant effect of interest in learning and mathematical resilience on students' understanding of mathematical concepts. The increasing interest in learning and motivation of mathematical resilience, the understanding of students' mathematical concepts will increase, and vice versa. The magnitude of interest in learning and mathematical resilience on students' understanding of mathematical concepts is $77.8 \%$. It shows that students' understanding of concepts in online learning is more dominated by students' interest in learning and mathematical resilience. Understanding mathematical concepts plays an important role in the activities of knowledge and skills in mathematics learning (Utami et al., 2020). Understanding the concept well requires interest (Lin et al., 2016) and mathematical resilience (Nurjannah \& Marlina, 2021).

Interest has a very important role in learning (Sutarto et al., 2020). Understanding student goals and being studentcentered is an important factor in stimulating student interest in learning (Shi, 2020). Interest in learning has a relationship with the ability to understand. Usually, students interested in learning have good scores on the comprehension test (Rachman, 2018). Interest will foster resilience in perseverance and willingness to discuss, reflect and research mathematics in students. Students become more aware of their learning and are better able to understand and know mathematics (Johnston-Wilder \& Lee, 2010). Mathematical resilience is needed when teachers intend to educate students to think and behave mathematically, not just to get good grades or pass math tests. Students with strong resilience will have the math skills needed to answer exam questions, and more importantly, they will also have the math skills needed outside of school and be eager to apply them whenever needed. Thus, in every learning, resilience is needed (Wibowo et al., 2018). Even the development of the times and current conditions requires individuals to have high resilience to carry out their daily lives (Beale, 2020). Students need high mathematical interest and resilience in online learning during the Covid-19 pandemic so that they will not easily give up when facing difficulties in learning mathematics (Amelia et al., 2020).

\section{Conclusion and Recommendations}

Students' interest in online learning has a significant influence on understanding the concept. Through interest can arouse students' curiosity about things that are not yet known. The attitude of curiosity that constantly arises because they feel challenged will form resilience. Simultaneously, interest and resilience showed a significant effect on understanding mathematical concepts. The percentage contribution of interest and resilience variables on understanding mathematical concepts is $77.8 \%$, while other variables influence the rest. 
Education during and after Covid-19 will be very different in many ways. However, interest and resilience need to be continuously instilled to always develop in various situations and conditions. Further research can be studied on a larger sample and can develop variables that influence online mathematics learning.

\section{References}

Amelia, R., Kadarisma, G., Fitriani, N., \& Ahmadi, Y. (2020). The effect of online mathematics learning on junior high school mathematic resilience during covid-19 pandemic. Journal of Physics: Conference Series, 1657, 012011. https://doi.org/10.1088/1742-6596/1657/1/012011

Aripin, U. (2015). Meningkatkan Kemampuan Pemahaman Matematik Siswa SMP Melalui Pendekatan Pembelajaran Berbasis Masalah. Jurnal Ilmiah P2M STKIP Siliwangi, 2(1), 120-127. https://doi.org/10.22460/p2m.v2i1p120-127.171

Azmidar, A., Darhim, D., \& Dahlan, J. A. (2017). Enhancing Students' Interest through Mathematics Learning. Journal of Physics: Conference Series, 895, 012072. https://doi.org/10.1088/1742-6596/895/1/012072

Beale, J. (2020). Academic Resilience and its Importance in Education after Covid-19. Journal for Innovation and Research in Education, 4, 6.

Benson-O'Connor, C. D., McDaniel, C., \& Carr, J. (2019). Bringing Maths to Life: Provide Students Opportunities to Connect their Lives to Math. Networks: An Online Journal for Teacher Research, 21(2). https://doi.org/10.4148/2470-6353.1299

Dewantoro, A., \& Rachmawati, I. (2020). Analysis of Evaluation and Exploratory Studies on Student's Resilience of Online Learning during Pandemic of Covid-19. KONSELI: Jurnal Bimbingan Dan Konseling (E-Journal), 7(2), 155-162. https://doi.org/10.24042/kons.v7i2.7422

Dini, M., Wijaya, T. T., \& Sugandi, A. I. (2018). Pengaruh Self Confidence Terhadap Kemampuan Pemahaman Matematik Siswa SMP. JURNAL SILOGISME : Kajian Ilmu Matematika dan Pembelajarannya, 3(1), 1-7. https://doi.org/10.24269/js.v3i1.936

Firdaus, F., Kailani, I., Bakar, Md. N. B., \& Bakry, B. (2015). Developing Critical Thinking Skills of Students in Mathematics Learning. Journal of Education and Learning (EduLearn), 9(3), 226-236. https://doi.org/10.11591/edulearn.v9i3.1830

Gafoor, K. A., \& Kurukkan, A. (2015). Why High School Students Feel Mathematics Difficult? An Exploration of Affective Beliefs. UGC Sponsored National Seminar on Pedagogy of Teacher Education- Trends and Challenges, 6.

Gustiani, S. (2020). Students' Motivation In Online Learning During Covid-19 Pandemic Era: A Case Study. Holistics Journal, 12(2), 18.

Hendriana, et al. (2017). Hard skills dan Soft skills Matematika Siswa. Refika Aditama.

Hodaňová, J., \& Nocar, D. (2016). Mathematics Importance In Our Life. Proceedings of INTED2016 Conference 7th9th March 2016, Valencia, Spain.. https://doi.org/10.21125/inted.2016.0172

Johnston-Wilder, S., \& Lee, C. (2010). Developing mathematical resilience. BERA Annual Conference 2010, University of Warwick. http://www.beraconference.co.uk/2010/

Kusmaryono. (2018). The Importance Of Mathematical Power In Mathematics Learning. International Conference on Mathematics, Science and Education 2017 (ICMSE2017).Journal of Physics: Conference Series, 983, 011001. https://doi.org/10.1088/1742-6596/983/1/011001

Lin, Y.-W., Tseng, C.-L., \& Chiang, P.-J. (2016). The Effect of Blended Learning in Mathematics Course. EURASIA Journal of Mathematics, Science and Technology Education, 13(3). https://doi.org/10.12973/eurasia.2017.00641a

Mawaddah, S., \& Jannah, R. (2017). Meningkatkan Kemampuan Pemahaman Matematis Siswa dengan Model Pembelajaran Quantum Teaching di Kelas XI SMA. EDU-MAT: Jurnal Pendidikan Matematika, 4(2), Article 2. https://doi.org/10.20527/edumat.v4i2.2574

Muhammad, H. (2020). Menyiapkan Pembelajaran di Masa Pandemi: Tantangan dan Peluang. Kementerian Pendidikan dan Kebudayaan. (https://spab.kemdikbud.go.id/wp-content/uploads/2020/07/MenyiapkanPembelajaran-di-Masa-Pandemi-1.pdf) 
Mujib, A., \& Yunita, Y. (2021). The Effectiveness Of Learning During A Pandemic Covid-19. Ri'ayah: Jurnal Sosial Dan Keagamaan, 5(02), 144. https://doi.org/10.32332/riayah.v5i02.2802

Mullis, I. V. S., Martin, M. O., Pierre, F., \& Hooper, M. (2015). TIMSS 2015 International Results in Mathematics. IEA TIMMS \& PIRLS International Study Center Lynch School of Education, Boston College. timss2015.org/download-center

Muthuprasad, T., Aiswarya, S., Aditya, K. S., \& Jha, G. K. (2021). Students' Perception And Preference For Online Education In India During Covid -19 Pandemic. Social Sciences \& Humanities Open, 3(1), 100101. https://doi.org/10.1016/j.ssaho.2020.100101

Nurjannah, A., \& Marlina, R. (2021). Analisis Resiliensi Dalam Pembelajaran Matematika Pada Siswa SMP. Jurnal Pendidikan Matematika, 12(2), 188-194. https://doi.org/10.36709/jpm.v12i2.18234

OECD. (2018). PISA 2018 Results COMBINED EXECUTIVE SUMMARIES VOLUME I, II \& III. OECD.

Permatasari, I., Rahayu, T., Mudofir, I., Aziz, M., \& Maaliah, E. (2021). Challenge in Learning English: Understanding Student Resilience. Proceedings of the First International Conference on Economics, Business and Social Humanities, ICONEBS 2020, November 4-5, 2020, Madiun, Indonesia. Proceedings of the First International Conference on Economics, Business and Social Humanities, ICONEBS 2020, November 4-5, 2020, Madiun, Indonesia, Madiun, Indonesia. https://doi.org/10.4108/eai.4-11-2020.2304551

Peter, E. E. (2011). Mathematics: Indispensable tool for successful and balance human existence on this planet. Advances in Applied Science Research, 2(5), 8.

Purwasih, R. (2015). Peningkatan Kemampuan Pemahaman Matematis Dan Self Confidence Siswa MTs Di Kota Cimahi Melalui Model Pembelajaran Inkuiri Terbimbing. Didaktik, 9(1), 16-25.

Rachman, D. (2018). Students' Interest in Learning English and Reading Understanding Ability Using Story Texts. JELE (Journal of English Language and Education), 4(1), 37. https://doi.org/10.26486/jele.v4i1.428

Romadon, S., \& Mahmudi, A. (2019). Penerapan Pendekatan Penemuan Terbimbing Untuk Meningkatkan Kemampuan Pemahaman Konsep Matematis Siswa. AKSIOMA: Jurnal Program Studi Pendidikan Matematika, 8(1), 5864. https://doi.org/10.24127/ajpm.v8i1.1684

Sari, I., Marwan, M., \& Hajidin, H. (2019). Students' Thinking Process in Solving Mathematical Problems in Build Flat Side Spaces of Material Reviewed from Adversity Quotient. Malikussaleh Journal of Mathematics Learning (MJML), 2(2). https://doi.org/10.29103/mjml.v2i2.1468

Shi, G. (2020). Research on the Influence of Online Learning on Students' Desire to Learn. Journal of Physics: Conference Series, 1693, 012055. https://doi.org/10.1088/1742-6596/1693/1/012055

Suhartini, D. (2018). Student's Learning Interest And Learning Outcomes In History Lesson. Historia: Jurnal Pendidik Dan Peneliti Sejarah, 11(2), 176. https://doi.org/10.17509/historia.v11i2.12381

Sutarto, S., Sari, D. P., \& Fathurrochman, I. (2020). Teacher strategies in online learning to increase students' interest in learning during COVID-19 pandemic. Jurnal Konseling Dan Pendidikan, 8(3), 129. https://doi.org/10.29210/147800

Trisniawati, T., Muanifah, M., Widodo, S., \& Ardiyaningrum, M. (2019). Effect of Edmodo towards interests in mathematics learning. Journal of Physics: Conference Series, 1188, 012103. https://doi.org/10.1088/1742$6596 / 1188 / 1 / 012103$

Utami, C., Anitra, R., \& Moseki, U. R. (2020). Understanding of Mathematical Concepts and Students' Self-Regulated Learning in RME Learning Assisted by PANDU. JETL (Journal of Education, Teaching and Learning), 5(2), 229. https://doi.org/10.26737/jetl.v5i2.2045

Vainikainen, M.-P., Salmi, H., \& Thuneberg, H. (2015). Situational Interest and Learning in a Science Center Mathematics Exhibition. https://doi.org/10.51355/jstem.2015.6

Wibowo, A., Slamet, I., \& Sudjadi, I. (2018). Construct Validity of Mathematical Resilience: Confirmatory Factor Analysis. University of Muhammadiyah Malang's 1st International Conference of Mathematics Education, 160. https://doi.org/10.2991/incomed-17.2018.55

Yadav, S. (2020). Role Of Mathematics In The Development Of Society. SSRN Electronic Journal, 6.

Yeh, C. Y. C., Cheng, H. N. H., Chen, Z.-H., Liao, C. C. Y., \& Chan, T.-W. (2019). Enhancing achievement and interest in mathematics learning through Math-Island. Research and Practice in Technology Enhanced Learning, 14(1), 5. https://doi.org/10.1186/s41039-019-0100-9 